\title{
Experimental infection of mice with Anisakis simplex
}

\author{
Israel Figueiredo Junior ${ }^{[1]}$, Gerlinde Teixeira ${ }^{[2]}$ and Mauricio Afonso Vericimo ${ }^{[2]}$
}

[1]. Departamento Materno-Infantil, Faculdade de Medicina, Universidade Federal Fluminense, Niterói, RJ. [2]. Departamento de Imunobiologia, Instituto de Biologia, Universidade Federal Fluminense, Niterói, RJ.

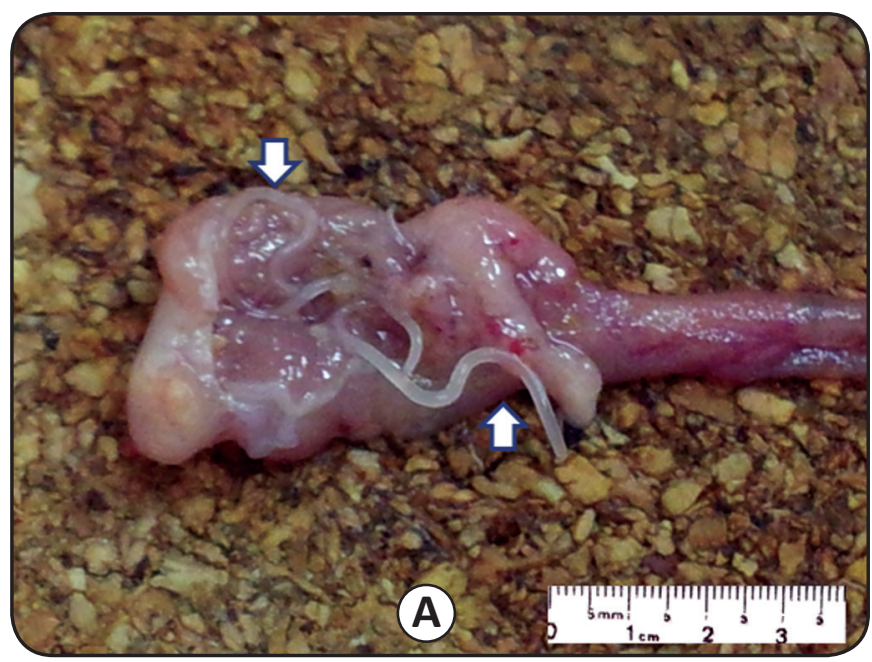

A photograph of third-stage (L3) Anisakis simplex larvae in the gastric cavity of BALB/c mice is provided here. Anisakis nematodes (Figure A; arrows) are white and cylindrical and measure approximately 2 to 3 centimeters in length. Human anisakiasis, an emerging disease often triggered by eating fish infected with Anisakis sp., is not widely studied in Latin America. Mouse models have been developed to emulate the human immune response to Anisakis infestation. These models, however, involve infection via the intraperitoneal route, rather than the oral route, which is the natural pathway of nematode entry in humans. It is believed that the establishment of an intestinal model of infection should involve the introduction of live larvae through the orogastric route. Our team has developed a simple, reproducible model of infection that allows for the introduction of viable larvae into mice via this route (video: http://www.uff.br/anisakis/ansakis\%205_0002.wmv).

\section{REFERENCES}

1. Audicana MT, Kennedy MW. Anisakis simplex: from obscure infectious worm to inducer of immune hypersensitivity. Clin Microbiol Rev 2008; 21:360-379.

2. Daschner A, Cuellar C, Rodero M. The Anisakis allergy debate: does and evolutionary approach help? Trends Parasitol 2012; 28:9-15.

3. Figueiredo Jr I, Cardoso L, Teixeira G, São Clemente S, Vericimo M. A technique for the intra-gastric administration of live larvae of Anisakis simplex in mice. Exp Parasitol 2012; 130:285-287.

Address to: Dr. Israel Figueiredo Junior. Depto Materno-Infantil/FM/HUAP/UFF. Av. Marques do Paraná 303, Centro, 24030-210 Niterói, RJ, Brasil. Phone: 5521 2620-1323; 5521 8212-3045

e-mail: ifigueiredo@id.uff.br

Received 03 November 2012

Accepted 19 February 2013 